\title{
Immunohistochemical Detection of Central Nervous Tissue in Meat Products
}

\author{
V. KUMMER, J. MAŠKOVÁ, E. RENČOVÁ \\ Veterinary Research Institute, Brno, Czech Republic
}

Received May 2, 2005

Accepted August 30, 2005

\begin{abstract}
Kummer V., J. Mašková, E. Renčová: Immunohistochemical Detection of Central Nervous Tissue in Meat Products. Acta Vet Brno 2005, 74: 449-454.

The aim of the study was to test the applicability of commercially available poly- and monoclonal antibodies intended for human nervous tissue, for immunohistochemical detection of central nervous tissue from farm animals in meat products. Testing of seven selected antibodies for the detection of neurofilaments, betaIII-tubulin, glial fibrillary acidic protein and myelin basic protein was focused on the assessment of their sensitivity and specificity and on the possibility to detect nervous tissue in the heat-treated meat products. Immunohistochemical examination of intact brain tissue and peripheral nerve from cattle, pig, sheep, goat and hen was performed. Specificity of antibodies was tested in samples of heart, diaphragm, liver, spleen, lymph node, lungs and uterus from cattle and pig. Brain tissue, bovine peripheral nerve samples and sausages containing $0,1,5$ or $10 \%$ of bovine brain tissue were heat-treated by boiling for 10 and 30 min and subsequently examined. All the samples were fixed in 10\% neutral buffered formalin and then embedded in paraffin. Immunoreaction specific for nervous tissue was only demonstrated by monoclonal anti-glial fibrillary acidic protein (ICN Biomedicals) and polyclonal anti-myelin basic protein (DakoCytomation) antibodies. The other tested antibodies demonstrated non-specific cross-reactivity with other tissues; they were consequently excluded from further investigation. Heat treatment of samples resulted in the loss of integrity of glial cells and evident decrease in the intensity of immunoreaction with anti-glial fibrillary acidic protein antibody. In contrast, particularly good results were obtained with the demonstration of myelin basic protein because no marked weakening of immunoreaction was recorded in brain tissue after $30 \mathrm{~min}$ heat treatment with boiling. The detection of nervous tissue in sausages with defined content of brain tissue after $30 \mathrm{~min}$ boiling was also unequivocal. The antibody is not species specific. After unification of the laboratory protocol and wider testing, immunohistochemical detection of nervous tissue in meat products using polyclonal antimyelin basic protein antibodies can suitably supplement the set of laboratory methods for food safety examination.
\end{abstract}

Food safety, BSE, brain tissue, glial fibrillary acidic protein, myelin basic protein

Scientific papers dealing with the association of bovine spongiform encephalopathy (BSE) and the occurrence of new variant of Creutzfeldt-Jacob disease in humans (Collinge et al. 1996; Colling e 1999) initiated adopting a number of measures to eliminate presence of specified risk material, particularly tissues of the central nervous system (CNS) in meat products. Development and practical introduction of relevant laboratory methods of nervous tissue identification in meat products is worthwhile to guarantee the adopted control systems for food safety.

The development of immunohistochemical (IHC) methods of CNS tissue detection in meat products and selection of nervous tissue markers followed the development of immunochemical methods (Lü cker et al. 1998; Schmidt et al. 1999; Lücker et al. 2000; Horlacher 2002; Overhoff and Lücker 2003). However, the number of IHC studies published so far is rather sparse and the first ones appeared only by the end of last century (Lücker et al. 1999; Wenisch et al. 1999). Monoclonal anti-neuron specific enolase antibody (anti-NSE, $\gamma \gamma$ enolase) was used for IHC detection of CNS tissue in heat-treated sausages containing different proportions $(0,7.4$ and $33.3 \%)$ of bovine brain tissue. The

Address for correspondence:

MVDr. Vladimír Kummer, CSc.

Veterinary Research Institute

Hudcova 70, 62132 Brno

Czech Republic
Phone: +420541212462

Fax: +420541211229

E-mail: kummer@vri.cz

http://www.vri.cz

http://www.vfu.cz/acta-vet/actavet.htm 
analysis showed a homogenous distribution of specifically immunopositive nervous tissue in the examined samples. Fragments of connective tissue and musculature markedly differed by negative immunoreaction from nervous tissue. However, because the heat treatment of meat products resulted in a high degree of nervous tissue destruction, the NSE detection by IHC was not fully satisfactory. Using monoclonal antibody anti-NSE (Camon, Wiesbaden, Germany) Wenisch et al. (2000) obtained similar results as the above mentioned authors; they viewed the IHC method of CNS tissue demonstration by NSE detection as a valuable enrichment of diagnostic methods. They also tested the possibility of detection of glial fibrillary acidic protein (anti-GFAP, Boehringer, Mannheim, Germany) in the same samples. However, the obtained results were not satisfactory. Whereas GFAP was a highly specific and sensitive marker for nervous tissue detection in raw material, non-specific, false positive reactions of connective tissue and musculature were observed in heat-treated products.

Aupperle et al. (2002) tested the possibility of the use of the following primary antibodies in raw CNS tissue samples and in heat-treated meat products $\left(80\right.$ or $120^{\circ} \mathrm{C}$ for $20 \mathrm{~min}$ ) containing $0,0.5,1$ and $2 \%$ of brain tissue: anti-neuron specific enolase (antiNSE, M 873, DAKO, Hamburg, Germany), anti-glial fibrillary acidic protein (antiGFAP, Z 334, DAKO, Hamburg, Germany), anti-neurofilament (anti-NF, MAB 5274, Chemicon, Hofheim, Germany), anti-myelin basic protein (anti-MBP, 1118099 , Boehringer, Mannheim, Germany) and anti-peripherin (NCL-PERIPH, Medac GmbH, Wedel, Germany). All of the used antibodies showed very good ability to detect the presence of nervous tissue in raw samples. Anti-peripherin only stained the cells of the peripheral nervous system and the immunoreaction with the brain tissue was negative. The best results for heat-treated products were obtained with anti-NF antibody. Slightly positive reaction in musculature was considered as non-specific; it was attributed to the leakage of the antigen from neurocytes due to increased permeability caused by heat treatment of the meat products. The other used antibodies (anti-GFAP, anti-NSE, antiMBP) seemed to be less suitable for IHC diagnosis in the heat-treated products due to non-specific reactions.

Tersteeg et al. (2002) selected the following antibodies for IHC detection of brain tissue $(0,1,5,10$ and $20 \%$ of bovine or $5 \%$ of porcine brain tissue) in heat-treated meat products (70 or $115{ }^{\circ} \mathrm{C}$ for $60 \mathrm{~min}$ ): monoclonal anti-NF (ICN Biomedicals, Aurora, USA), monoclonal anti-NSE (DAKO, Glostrup, Denmark), polyclonal anti-GFAP (Biotrend, Köln, Germany) and polyclonal anti-MBP (Biogenesis, Poole, UK). The best and reliable results with heat-treated products were unequivocally obtained using polyclonal anti-MBP antibody. In case anti-NF antibody was used, the intensity of immunostaining after the heat treatment was evidently lower, and anti-GFAP and anti-NSE antibodies showed to be unsuitable because of a very weak immunoreaction and a non-specific reaction of the background.

Suitability of the nervous tissue markers synaptophysin and synaptobrevin for IHC detection of nervous tissue in heat-treated meat products was not confirmed (W en is ch et al. 2004).

The aim of the present study was to test whether certain commercial poly- and monoclonal antibodies intended for human CNS are suitable for immunohistochemical demonstration of CNS tissue from farm animals. The attention was particularly concentrated on the assessment of the sensitivity and specificity of the antibodies, and their potential use for the detection of nervous tissue in heat-treated meat products.

\section{Materials and Methods}

The examined intact tissues and organs

Brain tissue from cattle, pig, sheep, goat, and hen was examined. Peripheral nerve, heart, diaphragm, spleen, lymph node, lungs, and uterus from cattle and pig were also examined. 
The examined heat-treated organs and meat products

The heat treatment of the examined samples was performed by boiling for 10 and $30 \mathrm{~min}$. Bovine brain tissue, peripheral nerve and market sausages (frankfurters, supplied by supermarket Billa) containing 0, 1, 5 and $10 \%$ of bovine brain were examined. Sausage with the content of brain tissue were made by addition of brain tissue into the basal product and mixed for 2 min (Moulinex model MC AW4, France). Thereafter, the mixture was put in PVC casings and heat-treated.

IHC protocol schedule

The samples were fixed in 10\% neutral buffered formalin solution for $24 \mathrm{~h}$. Paraffin sections $(6 \mu \mathrm{m})$ were processed according to routine laboratory procedure. In the de-waxed sections, heat-induced antigen retrieval was performed in a microwave oven for $3 \times 5 \mathrm{~min}$ and endogenous peroxidase activity was blocked with $3 \%$ $\mathrm{H}_{2} \mathrm{O}_{2}$ for $15 \mathrm{~min}$ at room temperature. Primary antibodies were diluted according to the manufacturer's instructions. Incubation was performed for $60 \mathrm{~min}$ at room temperature. For visualization, EnVision ${ }^{\mathrm{TM}_{+}}$system (DakoCytomation, Carpinteria, USA) was used with the incubation time $30 \mathrm{~min}$, and chromogen 0.03\% DAB (3,3'diaminobenzidine, Fluka Chemie AG, Buchs, Switzerland) with the incubation time $5 \mathrm{~min}$ at $37^{\circ} \mathrm{C}$. The sections were counterstained with Gill's hematoxylin. Negative control was prepared by replacement of primary antibody with control reagent (DakoCytomation, Carpinteria, USA) or by omitting the primary antibody. Phosphate buffered saline $(\mathrm{pH} 7.6)$ was used for dilution of antibodies and rinsing the sections.

The tested commercial antibodies and the used dilutions

Monoclonal anti-GFAP (clone GF-01, EXBIO, Prague, Czech Republic; 1:100); monoclonal anti-GFAP (clone GA-5; ICN Biomedicals, Aurora, USA; 1:100); polyclonal anti-MBP (code No. N 1546, DakoCytomation, Carpinteria, USA; diluted by the manufacturer); monoclonal anti-NF (clone NF-01; EXBIO, Prague, Czech Republic; 1:100); monoclonal anti-NF (clone NF-09; EXBIO, Prague, Czech Republic; 1:100); polyclonal anti-NF 200 (Sigma, Saint Louis, USA; 1:160); monoclonal anti-beta III-tubulin (clone TU-20; EXBIO, Prague, Czech Republic; 1:100).

Evaluation of the results

Sensitivity and specificity of primary antibodies was assessed by light microscopy examination of colour immunoreactions. The image analysis using LUCIA G software (Laboratory Imaging, Prague, Czech Republic) was used for semiquantitative evaluation of brain proportions in the examined sausages.

\section{Results}

\section{Intact tissues and organs}

All the tested antibodies were characterized by a good immunoreaction with the target cell structure in the brain tissue, i. e. they strongly demonstrated glial cells, neurofilamenta, tubulin and myelin basic protein. However, monoclonal anti-GFAP (ICN Biomedicals) and polyclonal anti-MBP (DakoCytomation) were the only antibodies that showed immunoreaction specific for exclusively nervous tissue (brain and peripheral nerve). The other tested commercial antibodies intended for human use, demonstrated a non-specific cross-reaction with cells from other tissues (musculature, connective tissue, uterine epithelium, hepatocytes and cells of the immune system). Higher dilution of the antibodies and a shorter incubation time did not affect non-specific immunoreaction of these antibodies (Plate X, Fig.1).

Anti-GFAP antibody (ICN Biomedicals) sensitively reacted with glial cells of brain (astrocytes) and peripheral nervous system (Schwann cells). Cross-reactions of the antibody with other cells and tissues were not observed (Plate XI, Fig. 2A). Species specificity (cattle, pig, sheep, goat, and hen) was not detected.

Anti-MBP antibody (DakoCytomation) demonstrated a strong immunobinding to myelinated nerve fibre in the brain and to myelin sheaths of peripheral nerves. Besides sufficient sensitivity, the antibody was highly specific, and did not show any signs of crossreactivity and non-specific binding to other cells and tissues (Plate XII, Fig. 3) similarly as anti-GFAP. Species specificity was not observed.

Due to the positive results in the intact tissue samples, only anti-GFAP (ICN Biomedicals) and anti-MBP (DakoCytomation) antibodies were selected for further testing of their suitability for IHC detection of nervous tissue in heat-treated meat products. 
Heat-treated tissues and meat products

Heat treatment of brain and peripheral nerves resulted in a marked decrease of immunoreaction when anti-GFAP antibody was used. Moreover, besides decreased intensity of immunostaining, boiling of the brain for 10 and $30 \mathrm{~min}$ resulted in glial cells integrity loss (Plate XI, Fig. 2B). The immunoreaction was negative in peripheral nerves after boiling for $30 \mathrm{~min}$, and nervous tissue particles in frankfurters were only occasionally detected, even where nervous tissue proportions were higher (5 and $10 \%$ ).

In contrast, very good results were obtained by the detection of myelin basic protein in heat-treated samples using polyclonal anti-MBP antibody. The reaction was not weaker either in brain or in peripheral nerve even after $30 \mathrm{~min}$ of heat treatment by boiling. Only a moderate diffusion of antigen was observed (Plate XIII, Fig 4A). The demonstration of nervous tissue in frankfurters containing brain tissue was unequivocal after $30 \mathrm{~min}$ boiling (Plate XIII, Fig. 4B), and the values obtained by the image analysis using LUCIA G software correlated well with the inclusion rate of nervous tissue (1,5 and 10\%) - (Table 1).

Table 1. Semiquantitative evaluation of CNS tissue content in frankfurters by image analysis LUCIA G software

\begin{tabular}{|c|c|c|c|c|c|c|c|c|}
\hline \multicolumn{3}{|c|}{ Frankfurter + 1\% CNS } & \multicolumn{3}{|c|}{ Frankfurter $+\mathbf{5} \%$ CNS } & \multicolumn{3}{|c|}{ Frankfurter $+10 \%$ CNS } \\
\hline Field No. & $\begin{array}{c}\text { Proportion } \\
(\%)\end{array}$ & $\begin{array}{c}\text { Total area } \\
\left(\mu \mathrm{m}^{2}\right)\end{array}$ & Field No. & $\begin{array}{c}\text { Proportion } \\
(\%)\end{array}$ & $\begin{array}{c}\text { Total area } \\
\left(\mu \mathrm{m}^{2}\right)\end{array}$ & Field No. & $\begin{array}{c}\text { Proportion } \\
(\%)\end{array}$ & $\begin{array}{c}\text { Total area } \\
\left(\mu \mathrm{m}^{2}\right)\end{array}$ \\
\hline 1 & 1.68 & 33,429 & 1 & 4.56 & 25,718 & 1 & 7.28 & 34,334 \\
\hline 2 & 0.68 & 63,856 & 2 & 4.84 & 62,474 & 2 & 10.97 & 70,444 \\
\hline 3 & 0.63 & 92,237 & 3 & 4.72 & 99,214 & 3 & 15.35 & 111,343 \\
\hline 4 & 0.57 & 131,897 & 4 & 6.26 & 134,265 & 4 & 11.56 & 154,217 \\
\hline 5 & 0.36 & 164,275 & 5 & 8.63 & 168,582 & 5 & 13.53 & 188,105 \\
\hline 6 & 0.66 & 194,769 & 6 & 3.41 & 205,244 & 6 & 12.83 & 224,780 \\
\hline 7 & 0.52 & 231,950 & 7 & 2.97 & 240,683 & 7 & 13.02 & 267,056 \\
\hline 8 & 0.67 & 264,340 & 8 & 8.91 & 271,829 & 8 & 6.92 & 294,719 \\
\hline 9 & 1.59 & 293,319 & 9 & 4.74 & 302,153 & 9 & 15.53 & 328,609 \\
\hline 10 & 0.67 & 327,308 & 10 & 5.52 & 340,118 & 10 & 5.07 & 358,124 \\
\hline Mean & 0.80 & 327,308 & Mean & 5.46 & 340,118 & Mean & 11.21 & 358,124 \\
\hline
\end{tabular}

\section{Discussion}

The results described in publications dealing with IHC detection of CNS tissue in meat products evidently differ even between the studies using identical marker of nervous tissue. It might have been caused by a different provenience and types of the monoclonal or polyclonal antibodies used. Cross-reactivity and the resulting differences in specificity and sensitivity of antibodies might have been caused by their binding to different antigenic determinants. The loss of the antigenic determinant during preparation of the sections (fixation and denaturation of proteins) and different protocols such as blocking of nonspecific and non-immune bindings, revitalization of the antigen, different detection systems etc. might have been other causes.

In a majority of commercial antibodies, particularly intended for the use in human tissues, specificity for nervous tissues of animals is not declared. According to our experience, cross-immunoreactions with cell proteins of other tissues are often found if those antibodies are used for the demonstration of nervous tissue from animals. The results of immunoreactions using antibodies against basic markers of nervous tissue (NSE, NF, GFAP and MBP) in intact samples of CNS tissue are generally good. Some differences may be recorded when mono- or polyclonal antibodies are used. Using monoclonal anti-MBP antibodies, Aupperle et al. (2002) referred to species specificity for bovine but not porcine brain tissue, and likewise on a negative reaction in peripheral nerves. In the present 
study using polyclonal antibody, species specificity was not recorded, which is in agreement with Tersteeg et al. (2002); the immunoreaction of myelin sheaths in peripheral nerves was also positive. If it is necessary to differentiate between brain tissue and peripheral nerves in the examined sample, anti-peripherin antibody (Aupperle et al. 2002) can be used.

Differences can also be observed in heat-treated meat products. Whereas Aupperle et al. (2002) considered the use of monoclonal anti-MBP antibody as less suitable due to a markedly weakened immunoreaction and non-specific reactions, in the present study, evidently best and reliable results were obtained with polyclonal anti-MBP in concord with Tersteeg et al. (2002). Various studies refer to a very similar view on the limited use of anti-GFAP antibodies for the detection of nervous tissue in heat-treated meat products due to a markedly weakened immunoreaction (Wenisch et al. 2002; Aupperle et al. 2002; Tersteeg et al. 2002).

It follows from the testing of certain commercial antibodies that polyclonal anti-MBP antibody (DakoCytomation) is evidently best for the detection of myelin basic protein. The results show a high sensitivity and specificity of this antibody and even a long-time heat treatment of meat products does not essentially affect the intensity of immunostaining. After unification of the laboratory protocol and wider testing, the IHC detection of nervous tissue in meat products using polyclonal anti-MBP antibodies can suitably supplement the set of laboratory methods for food safety examination. The antibody is not species specific. Further investigation should be focused on the selection or development of primary antibodies that would be able not only to detect nervous tissue in heat-treated meat products, but also to determine the animal species origin.

\section{Imunohistochemická detekce centrální nervové tkáně v masných výrobcích}

Cílem práce bylo ověřit možnost využití některých komerčních protilátek, určených pro použití na lidských tkáních $\mathrm{k}$ imunohistochemickému průkazu tkáně centrálního nervového systému hospodářských zvířat. Testování sedmi vybraných protilátek pro průkaz neurofilament, betaIII-tubulinu, gliového fibrilárního kyselého proteinu a myelinového bazického proteinu bylo zaměřeno na posouzení jejich citlivosti a specifičnosti a na možnost detekce nervové tkáně po tepelném opracování masných výrobků. Imunohistochemickému vyšetření byla podrobena tkáň mozku a periferní nerv od skotu, prasete, ovce, kozy a slepice. Specifičnost protilátek byla testována na vzorcích srdce, bránice, jater, sleziny, mízní uzliny, plic a dělohy skotu a prasete. Vyšetření po tepelném opracování vzorků varem po dobu 10 a 30 min bylo provedeno na tkáni mozku a periferním nervu skotu a na párcích s příměsí $0,1,5$ a 10 \% tkáně mozku skotu. Všechny vyšetřované vzorky byly fixovány v $10 \%$ neutrálním pufrovaném formalinu a poté zality do parafinu. Specifickou imunoreakci pro nervovou tkán̆ vykazovaly pouze monoklonální protilátka proti gliovému fibrilárnímu kyselému proteinu (ICN Biomedicals) a polyklonální protilátka proti myelinovému bazickému proteinu (DakoCytomation). Ostatní ověřované protilátky projevovaly nespecifickou, zkř́iženou reaktivitu s jinými tkáněmi a byly proto $\mathrm{z}$ dalšího sledování vyloučeny. Tepelné opracování vzorků vedlo ke ztrátě integrity gliových buněk a k výraznému snížení intenzity imunoreakce s protilátkou proti gliovému fibrilárnímu kyselému proteinu. Naopak velmi dobré výsledky poskytla detekce myelinového bazického proteinu, když ani po 30 min tepelného ošetření varem nebyl ve tkáni mozku zaznamenán výraznější útlum imunoreakce. Také v párcích s definovanou přiměsí tkáně mozku byl i po 30 min varu průkaz nervové tkáně jednoznačný. Protilátka není druhově specifická. Imunohistochemická detekce nervové tkáně $\mathrm{v}$ masných výrobcích s využitím polyklonální protilátky proti myelinovému bazickému proteinu může být po unifikování 
pracovního protokolu a po širším ověření vhodným doplňkem laboratorních metod určených pro kontrolu bezpečnosti potravin.

\section{Acknowledgements}

The study was supported by the Ministry of Agriculture of the Czech Republic (project No. MZE 0002716201).

\section{References}

AUPPERLE H, LÜCKER E, OVERHOFF M, SCHOON HA 2002: Procedures for the unwanted ingredients in meat products with regard to BSE. 6. Immunohistochemical procedures for the detection of central and peripheral nervous tissue in meat products. Fleischwirtschaft 82: 100-104

COLLINGE J, SIDDLE KCL, MEADS J, IRONSIDE J, HILL AF 1996: Molecular analysis of prion strain variation and the aetiology of ,new variant" $C J D$. Nature 383: 685-690

COLLINGE J 1999: Variant Creutzfeldt-Jacob disease. Lancet 354: 317-323

HORLACHER S 2002: Nachweis von zentralnervösem Gewebe in Lebensmitteln in Hinblick auf die bovine spongiforme Enzephalopathie (BSE). Diss Justus-Liebig-Universität Giessen, 263 pp.

LÜCKER E, EIGENBRODT E, BÜLTE M 1998: Procedures for the detection of unwanted ingredients in meat products with regard to bovine spongiform encephalopathy (BSE). Fleischwirtschaft 78: 896-898

LÜCKER E, EIGENBRODT E, WENISCH S, FAILING K, LEISER R, BÜLTE M 1999: Development of an integrated procedure for the detection of central nervous tissue in meat products using cholesterol and neuronspecific enolase as markers. J Food Protect 62: 268-276

LÜCKER E, EIGENBRODT E, WENISCH S, LEISER R, BÜLTE M 2000: Identification of central nervous tissue in retail meat products. J Food Protect 63: 258-263

OVERHOFF M, LÜCKER E 2003: Suitability of monoclonal antibodies for the specific identification of central nervous tissue in meat and meat products. Fleischwirtschaft 83: 93-96

SCHMIDT GR, HOSSNER KL, YEMM RS, GOULD DH, O'CALLAGHAN JP 1999: An enzyme-linked immunosorbent assay for glial fibrillary acidic protein as an indicator of the presence of brain or spinal cord in meat. J Food Protect 62: 394-397

TERSTEEG MHG, KOOLMEES PA, VAN KNAPEN F 2002: Immunohistochemical detection of brain tissue in heated meat products. Meat Sci 61: 67-72

WENISCH S, LÜCKER E, EIGENBRODT E, LEISER R, BÜLTE M 1999: Detection of central nervous tissue in meat products - An immunohistochemical approach. Nutr Res 19: 1165-1172

WENISCH S, LÜCKER E, EIGENBRODT E, BÜLTE M, LEISER R 2000: Procedures for the unwanted ingredients in meat products with regard to BSE. 4. Histological and immunohistological procedures for the detection of central nervous tissue in meat products. Fleischwirtschaft 80: 69-72

WENISCH S, HERDE K, LANG C, LEISER R, BERGMANN R 2004: Investigations into the suitability of synaptophysin and synaptobrevin as markers of central nervous tissue in heat-treated meat products. Fleischwirtschaft 84: 112-114 
Plate X

Kummer V. et al.: Immunohistochemical ... pp. 449-454

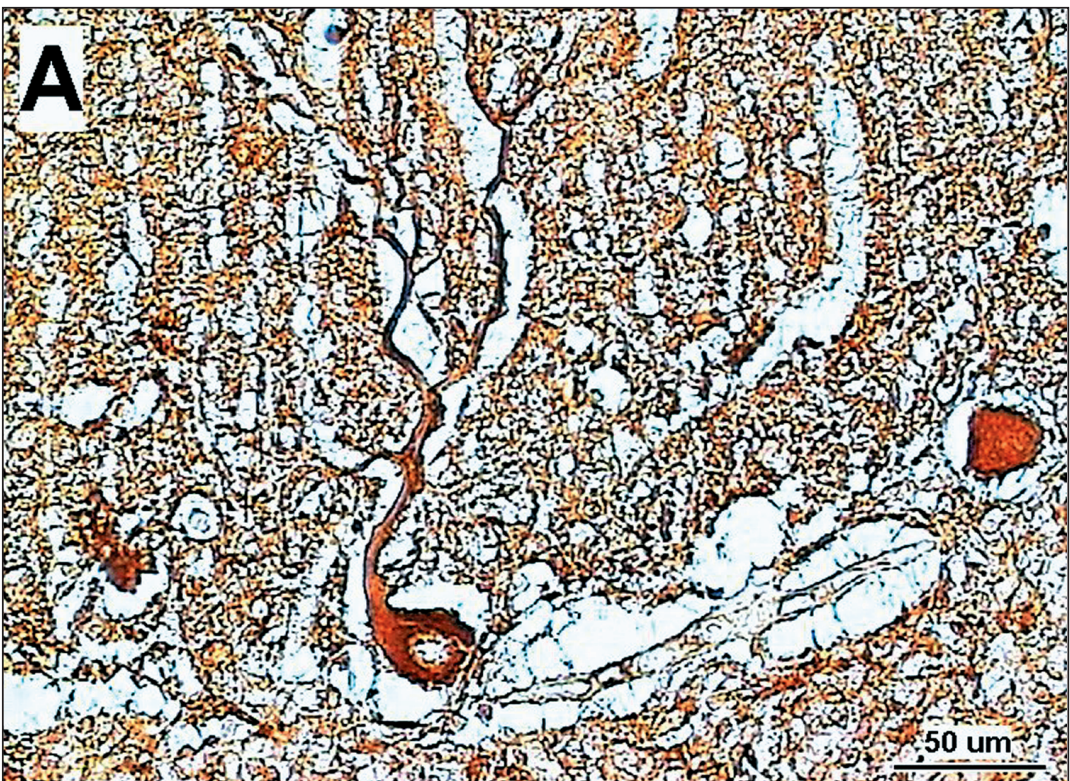

Fig. 1. Immunohistochemical staining for neurofilaments using polyclonal anti-NF 200 (Sigma, Saint Louis, USA) - A - positive immunoreaction of neurofilaments in bovine brain

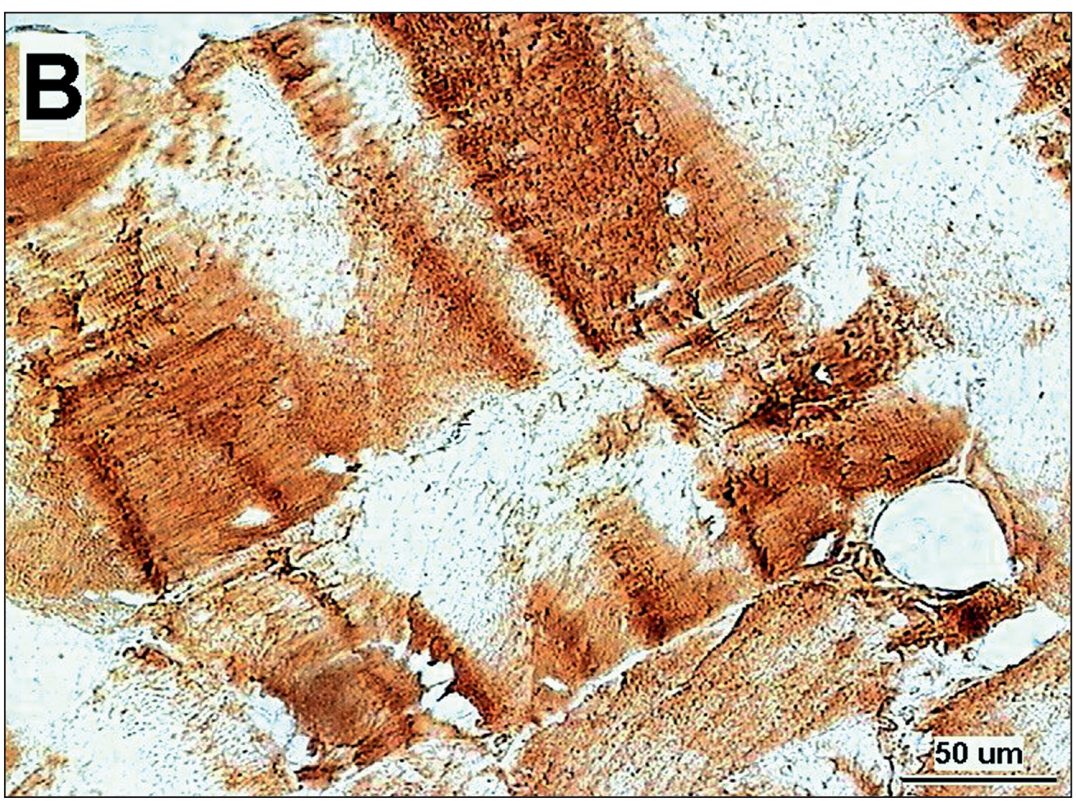

$\mathrm{B}$ - non-specific immunoreaction in bovine myocardium 


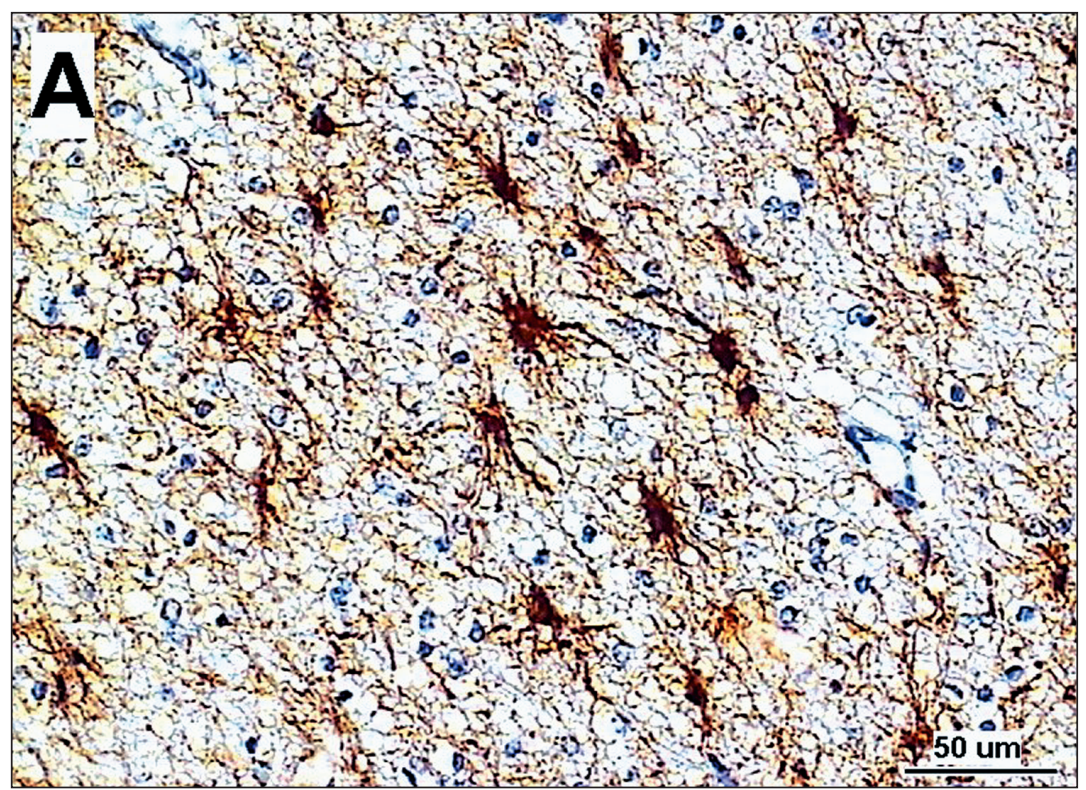

Fig. 2. Immunohistochemical staining for glial fibrillary acidic protein using monoclonal antiGFAP

(clone GA-05; ICN Biomedicals, Aurora, USA) - A - positive immunoreaction of glial cells (astrocytes)

in bovine brain

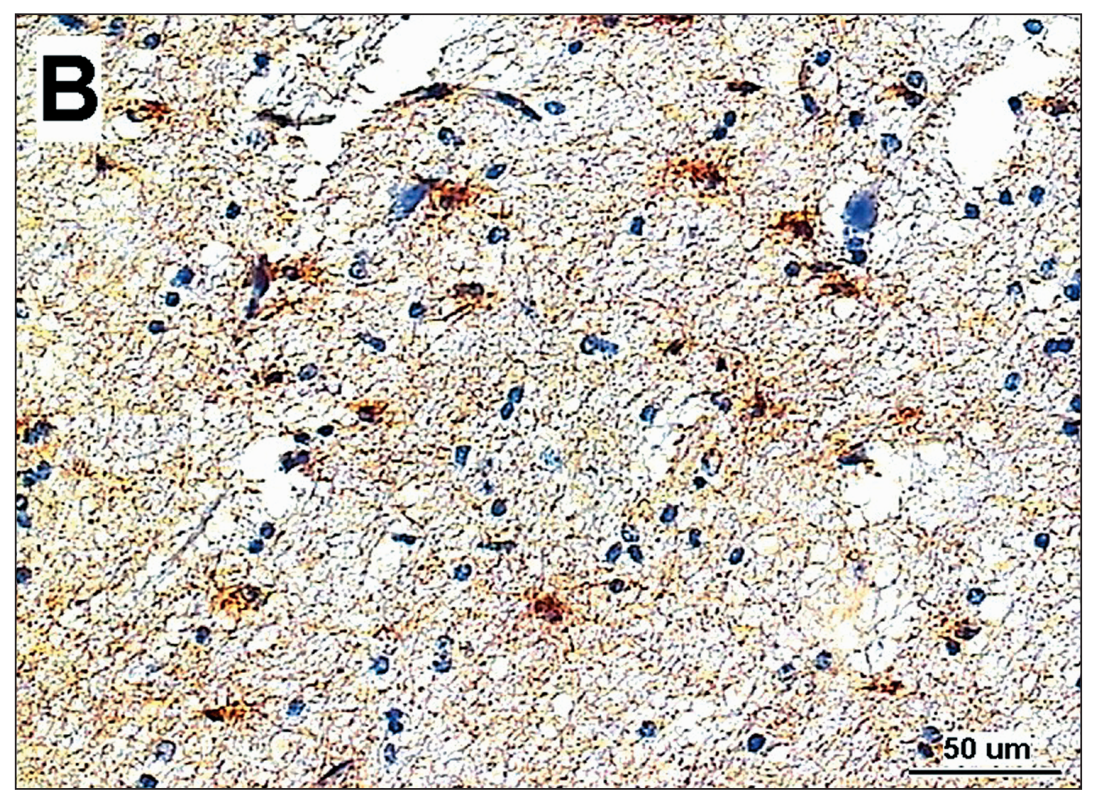

$\mathrm{B}$ - disintegration of glial cells and suppression of immunoreaction after boiling for $10 \mathrm{~min}$ Counterstained with hematoxylin. 


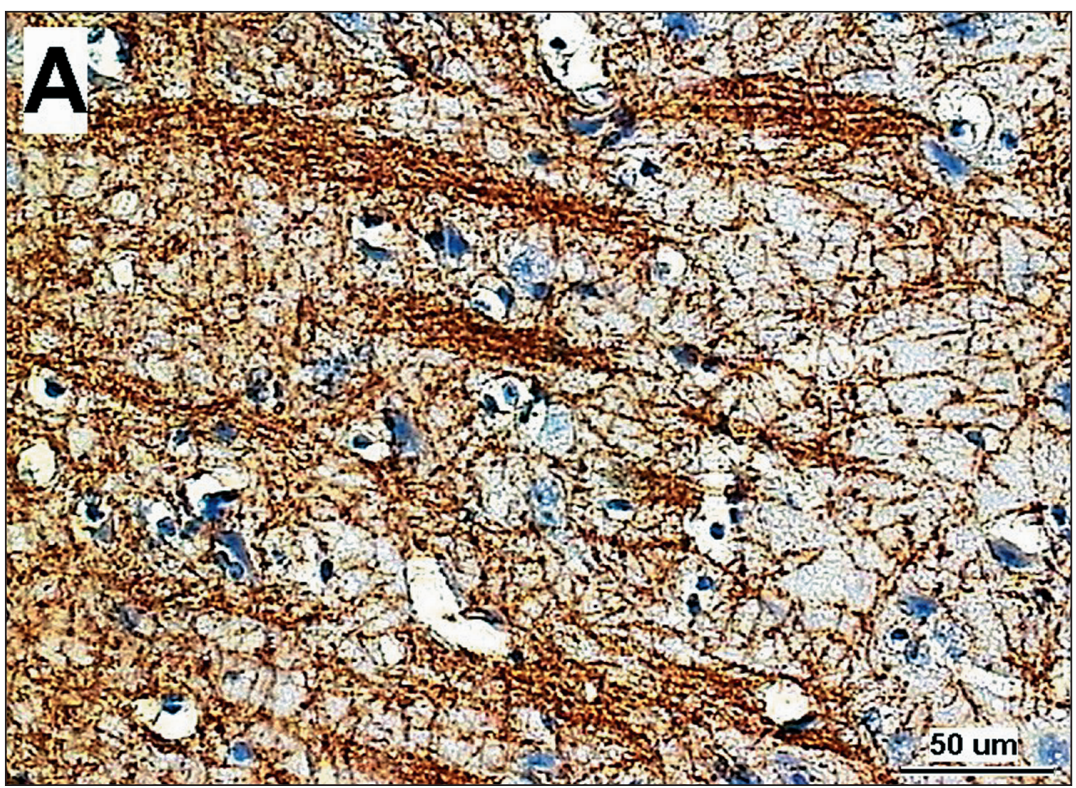

Fig. 3. Immunohistochemical staining for myelin basic protein using polyclonal anti-MBP (code No. N 1546; DakoCytomation, Carpinteria, USA) - A - positive immunoreaction of myelinated nerve fibre in bovine brain

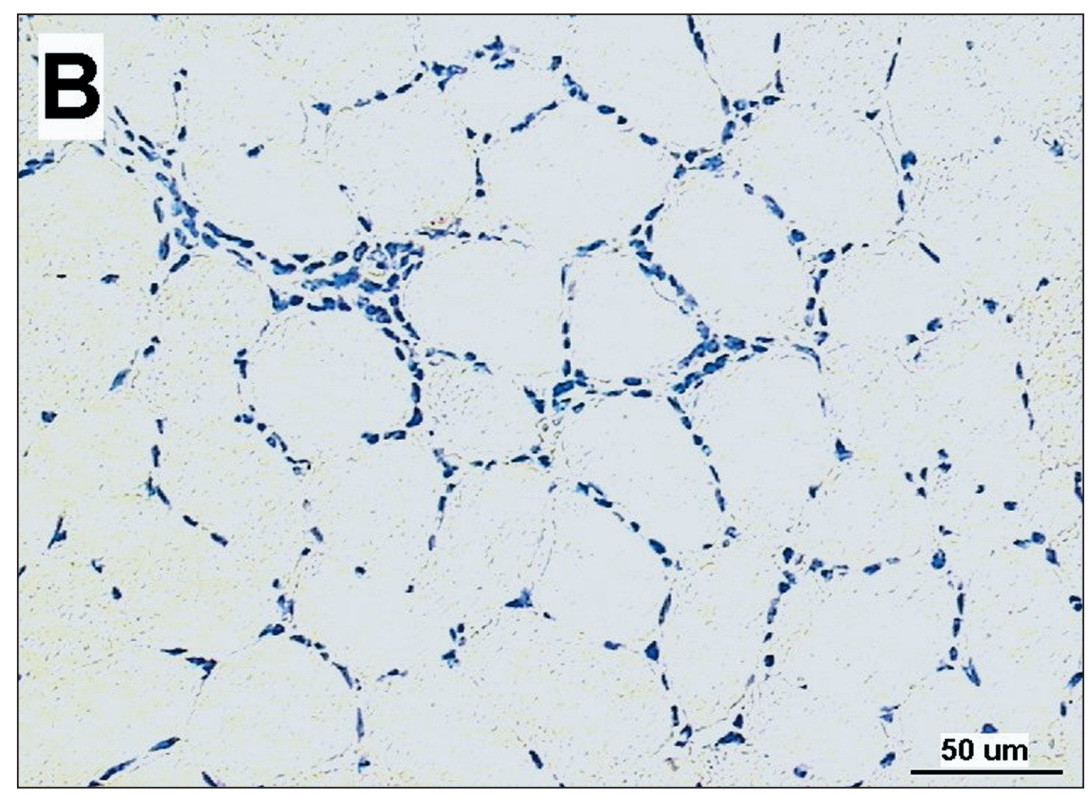

$\mathrm{B}$ - negative immunoreaction in bovine diaphragm Counterstained with hematoxylin. 


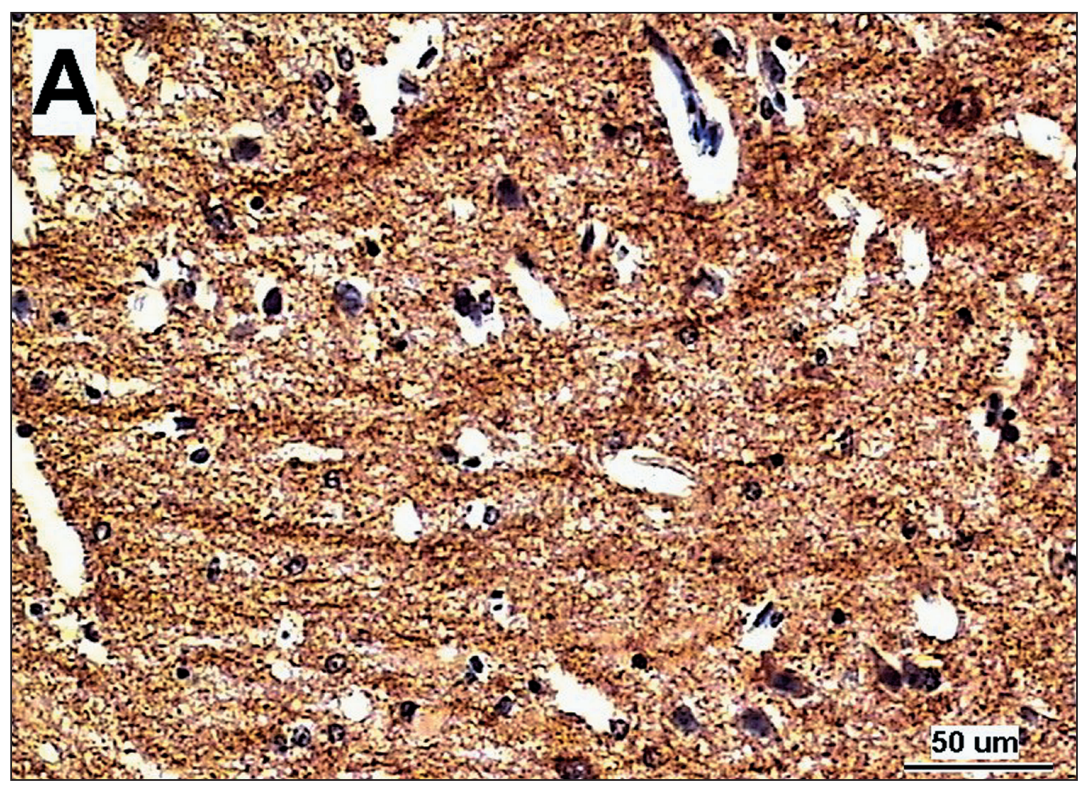

Fig. 4. Immunostaining with polyclonal anti-MBP (code No. N 1546; DakoCytomation, Carpinteria, USA) in heated samples - A - fully maintained immunoreaction with light diffusion of antigen after boiling for $30 \mathrm{~min}$, bovine brain

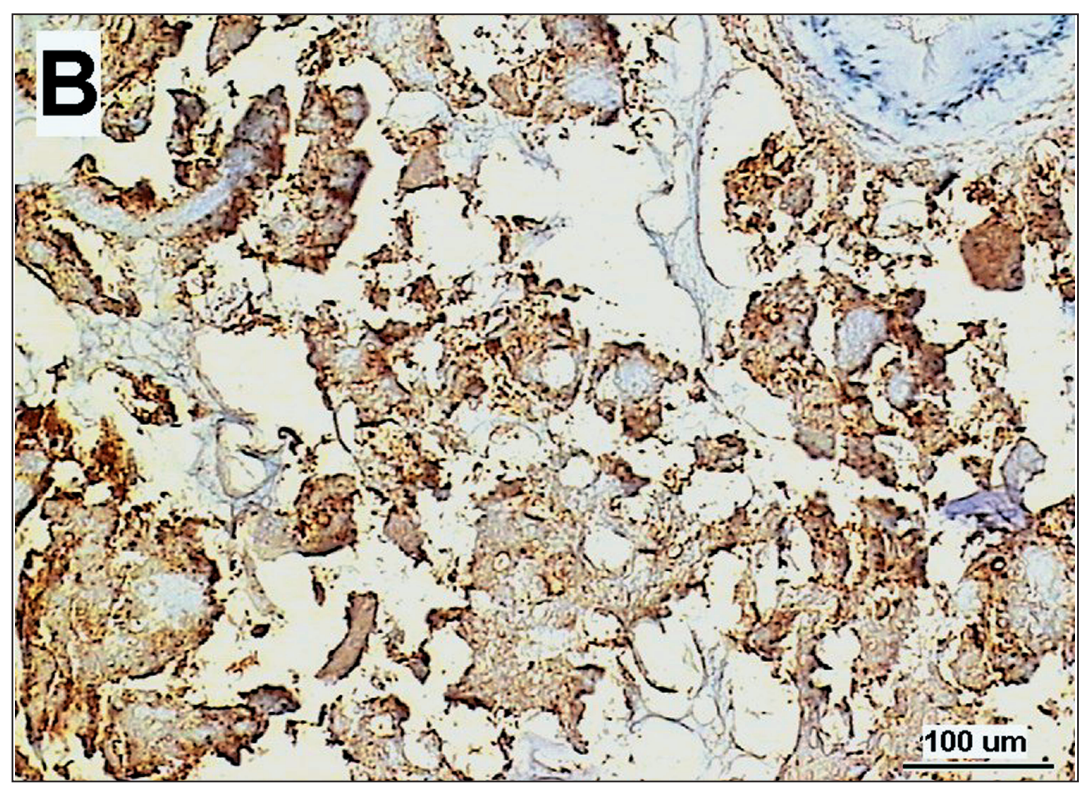

B - marked occurrence of immunopositive particles in sausage with $10 \%$ bovine brain tissue Counterstained with hematoxylin. 